\section{Commentary: External stenting of saphenous vein grafts- reinVESTing to achieve best returns in coronary artery bypass grafting}

\author{
Alex Nantsios, MD, Thin Xuan Vo, MD, MSc, and \\ Marc Ruel, MD, MPH
}

Coronary artery bypass grafting $(\mathrm{CABG})$ remains the standard of care for left main and multivessel coronary disease. Although multiarterial revascularization correlates with benefits, the saphenous vein graft (SVG) remains the ubiquitous conduit (in addition to left internal mammary artery) due to ease of harvest, flexibility of application, and accommodating potential for flow. A significant limitation of SVGs is graft failure. Early SVG failure is generally related to technical factors, whereas late failure is attributable to intimal hyperplasia (IH) and progression of atherosclerosis. ${ }^{1,2}$ There have been numerous efforts to improve SVG patency, as graft failure correlates with poorer outcomes. ${ }^{3,4}$ Pharmacologic measures, including aspirin ${ }^{5}$ and statins, ${ }^{6,7,8}$ have led to improved survival. Clopidogrel may provide an additive benefit,${ }^{9,10}$ especially in off-pump CABG. ${ }^{11}$ Surgically, focus on "no-touch" SVG harvesting, use of novel preservation solutions, and various grafting configurations have also been studied. ${ }^{1}$ ExExternal stents have been proposed as a technique to maximize graft patency by reducing shear stress and IH. In the randomized trial, VEST III, Taggart and colleagues ${ }^{12}$ investigated the effectiveness of SVG external stenting in reducing SVG failure. The authors found that patency rates were similar between stented and nonstented SVGs. However, Fitzgibbon patency scores, which indicate the severity of intimal irregularities, were significantly improved after external stenting at 2-year follow-up, and IH was reduced on intravascular ultrasound.

The authors should be commended for this well-designed trial studying an emerging technology to prevent SVG disease

\footnotetext{
From the Division of Cardiac Surgery, University of Ottawa Heart Institute, Ottawa, Ontario, Canada.

Disclosures: The authors reported no conflicts of interest.

The Journal policy requires editors and reviewers to disclose conflicts of interest and to decline handling or reviewing manuscripts for which they may have a conflict of interest. The editors and reviewers of this article have no conflicts of interest.

Received for publication April 11, 2021; revisions received April 11, 2021; accepted for publication April 12, 2021; available ahead of print April 18, 2021.

Address for reprints: Marc Ruel, MD, MPH, University of Ottawa Heart Institute, Suite 3402, 40 Ruskin St, Ottawa, Ontario K1Y 4W7, Canada (E-mail: mruel@ ottawaheart.ca).

J Thorac Cardiovasc Surg 2022;164:1542-3

$0022-5223 / \$ 36.00$

Copyright $($ c 2021 by The American Association for Thoracic Surgery

https://doi.org/10.1016/j.jtcvs.2021.04.032
}

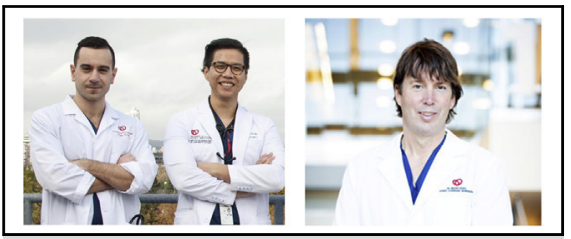

Alex Nantsios, MD (left), Thin Xuan Vo, MD, MSc (middle), and Marc Ruel, MD, MPH (right)

\section{CENTRAL MESSAGE \\ External stents have been proposed to reduce saphenous vein graft failure. While they may improve angiographic outcomes, focus should remain on surgical tech- nique and optimal medical therapy.}

progression. However, the adoption of SVG stenting as an adjunctive therapy must be cautioned at this time. First, SVG stenting was designed to improve long-term patency but fell short of this clinical benefit at 2-year follow-up. Although intimal irregularities measured by the Fitzgibbon patency score may predict subsequent graft occlusion, ${ }^{13}$ they have yet to be linked to clinical outcomes apart from repeat revascularization. ${ }^{3}$ Based on its within-patient control design, this study was not designed to show whether these anatomic differences translate into clinical end points. Furthermore, the majority of graft occlusions occurred during the first 6 months (68.4\%), generally attributed to technical shortcomings, highlighting opportunities for surgical improvement. Notably, the mean age in this patient cohort was $66.6 \pm 7.9$ years with a mean body mass index of $28.6 \pm 4.4$ and low rate of diabetes $(29.5 \%)$, suggesting these patients might have benefitted from further arterial revascularization.

Our current focus should therefore be realigned to areas in which differences can be made to fully benefit patients undergoing CABG. Multiple arterial grafting with appropriate conduits, including the addition of a radial artery graft, and careful target selection should be used for all possible candidates. Uncompromised surgical technique with minimal manipulation of the SVG and confirmation of graft runoff with intraoperative flow assessment are essential ${ }^{14}$ in preventing early SVG failure. To prevent disease progression, surgeons should continue to institute careful post-CABG guideline-directed medical therapy, including antiplatelet and statin therapy, ${ }^{8}$ in addition to smoking cessation ${ }^{15}$ and aggressive management of 
hypertension and diabetes, using modern therapies that may confer additional cardiovascular benefit (ie, GLP1 inhibitors, SGLT2 inhibitors). Although Taggart and colleagues ${ }^{12}$ provide compelling early anatomic results, the long-term reduction in SVG failure brought on by vesting remains unknown, and subsequent clinical outcomes will need to be ascertained. We are nonetheless grateful and better informed as a result of their mechanistic findings and look forward to longer-term outcomes from the VEST III trial.

\section{References}

1. Caliskan E, de Souza DR, Böning A, Liakopoulos OJ, Choi YH, Pepper J, et al. Saphenous vein grafts in contemporary coronary artery bypass graft surgery. Nat Rev Cardiol. 2020;17:155-69.

2. Moshkovitz Y, Raanani E. The art of saphenous vein grafting and patency maintenance. J Thorac Cardiovasc Surg. 2016;151:300-2.

3. Halabi AR, Alexander JH, Shaw LK, Lorenz TJ, Liao L, Kong DF, et al. Relation of early saphenous vein graft failure to outcomes following coronary artery bypass surgery. Am J Cardiol. 2005;96:1254-9.

4. Lopes RD, Mehta RH, Hafley GE, Williams JB, Mack MJ, Peterson ED, et al; Project of Ex Vivo Vein Graft Engineering via Transfection IV (PREVENT IV) Investigators. Relationship between vein graft failure and subsequent clinical outcomes after coronary artery bypass surgery. Circulation. 2012;125:749-56.

5. Goldman S, Copeland J, Moritz T, Henderson W, Zadina K, Ovitt T, et al. Saphenous vein graft patency one year after coronary artery bypass surgery and effects of antiplatelet therapy. Circulation. 1989;80:1190-7.

6. Kulik A, Abreu AM, Boronat V, Ruel M. Impact of lipid levels and high-intensity statins on vein graft patency after CABG: midterm results of the ACTIVE trial. $J$ Card Surg. 2020;35:3286-93.
7. Kulik A, Voisine P, Mathieu P, Masters RG, Mesana TG, Le May MR, et al. Statin therapy and saphenous vein graft disease after coronary bypass surgery: analysis from the CASCADE randomized trial. Ann Thorac Surg. 2011;92: 1284-90.

8. Kulik A, Ruel M, Jneid H, Ferguson TB, Hiratzka LF, Ikonomidis JS, et al; American Heart Association Council on Cardiovascular Surgery and Anesthesia. Secondary prevention after coronary artery bypass graft surgery: a scientific statement from the American Heart Association. Circulation. 2015; 131:927-64.

9. Kulik A, Le May MR, Voisine P, Tardif JC, Delarochelliere R, Naidoo S, et al. Aspirin plus clopidogrel versus aspirin alone after coronary artery bypass graft ing: the clopidogrel after surgery for coronary artery disease (CASCADE) Trial. Circulation. 2010;122:2680-7.

10. Hage A, Voisine P, Erthal F, Larose É, Glineur D, Chow B, et al. Eight-year follow-up of the Clopidogrel After Surgery for Coronary Artery Disease (CASCADE) trial. J Thorac Cardiovasc Surg. 2018;155:212-22.e2.

11. Deo SV, Dunlay SM, Shah IK, Altarabsheh SE, Erwin PJ, Boilson BA, et al. Dua anti-platelet therapy after coronary artery bypass grafting: is there any benefit? A systematic review and meta-analysis. J Card Surg. 2013;28:109-16.

12. Taggart DP, Gavrilov Y, Krasopoulos G, Rajakaruna C, Zacharias J, De Silva R, et al. External stenting and disease progression in saphenous vein grafts two years after coronary artery bypass grafting: a multicenter randomized trial. $J$ Thorac Cardiovasc Surg. 2022;164:1532-41.e2.

13. FitzGibbon GM, Leach AJ, Keon WJ, Burton JR, Kafka HP. Coronary bypass graft fate. Angiographic study of 1,179 vein grafts early, one year, and five years after operation. J Thorac Cardiovasc Surg. 1986;91:773-8.

14. Kieser TM, Rose S, Kowalewski R, Belenkie I. Transit-time flow predicts outcomes in coronary artery bypass graft patients: a series of 1000 consecutive arterial grafts. Eur J Cardiothorac Surg. 2010;38:155-62.

15. van Domburg RT, Meeter K, van Berkel DF, Veldkamp RF, van Herwerden LA, Bogers AJ. Smoking cessation reduces mortality after coronary artery bypass surgery: a 20-year follow-up study. J Am Coll Cardiol. 2000;36:878-83.

\section{Commentary: A device solution for the saphenous vein graft's infamous foible?}

\section{Brittany A. Zwischenberger, MD, ${ }^{a}$ and Mario Gaudino, MD, PhD, $\mathrm{MSCE}^{\mathrm{b}}$}

The choice of graft in coronary artery bypass grafting $(\mathrm{CABG})$ beyond the sturdy left internal mammary artery

From the ${ }^{\mathrm{a} D i v i s i o n}$ of Cardiovascular and Thoracic Surgery, Department of Surgery, Duke University, Durham, NC; and ${ }^{\mathrm{b}}$ Department of Cardiothoracic Surgery, Weill Cornell Medicine, New York, NY.

Disclosures: Dr Zwischenberger is a subinvestigator for US-VEST. Dr Gaudino reported no conflicts of interest.

The Journal policy requires editors and reviewers to disclose conflicts of interest and to decline handling or reviewing manuscripts for which they may have a conflict of interest. The editors and reviewers of this article have no conflicts of interest.

Received for publication April 13, 2021; revisions received April 13, 2021; accepted for publication April 15, 2021; available ahead of print April 20, 2021.

Address for reprints: Mario Gaudino, MD, PhD, MSCE, Division of Cardiovascular and Thoracic Surgery, Department of Cardiothoracic Surgery, Weill Cornell Medicine, 525 E 68th St, New York, NY 10065 (E-mail: mfg9004@med.cornell.edu).

J Thorac Cardiovasc Surg 2022;164:1543-5

$0022-5223 / \$ 36.00$

Copyright (c) 2021 by The American Association for Thoracic Surgery

https://doi.org/10.1016/j.jtcvs.2021.04.045

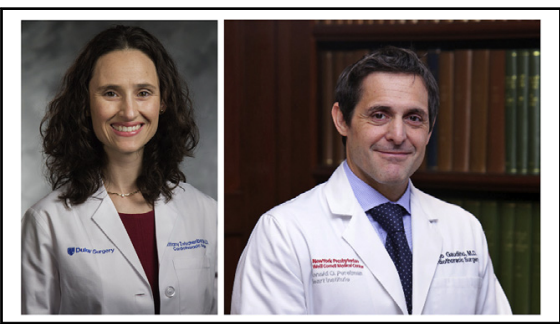

Brittany A. Zwischenberger, MD (left), and Mario Gaudino, MD, PhD, MSCE (right)

CENTRAL MESSAGE

In patients undergoing coronary

artery bypass grafting with

saphenous vein grafting, external

stenting of the vein grafts may

reduce late degeneration.

remains a challenge as surgeons weigh the risks, benefits, and scientific evidence surrounding radial artery, right 